Gut, 1960, 1, 248.

\title{
GASTRIC ACTIVITY IN THE SOUTH AFRICAN EUROPEAN AND BANTU
}

\author{
BY \\ I. MACDONALD* \\ From the Department of Physiology, University of the Witwatersrand, Johannesburg
}

Test meals in Europeans and Bantu in Johannesburg show that the stomachs of normal Europeans in the main secrete more acid and pepsin.

Gastric studies in Bantu on a European diet compared with those on a more non-European type of diet reveal no difference in secretory behaviour. This, it is suggested, rules out current dietary habits as being responsible for the difference in gastric secretory behaviour found between European and Bantu.

The Bantu on a European diet had a slower rate of gastric emptying than those on a non-European diet.

The incidence of peptic ulceration is low in the South African Bantu as compared with the European living in that country. Eagle and Gillman (1938), as a result of examining Government and hospital post-mortem records in South Africa, declared that the European is apparently seven times more susceptible to peptic ulcer than the Bantu. Many factors may contribute to this difference in incidence of peptic ulceration and it was felt that it would be useful to know the gastric "background" upon which the factors responsible for ulceration had to operate.

\section{METHODS}

The subjects were volunteers from three groups of persons. One group consisted of 11 medical students of European ancestry aged 19-21 years, a second group was made up of nine Bantu laboratory assistants aged 25-39 years working in the department, while the third group contained eight Bantu undergraduates aged 18-26 years.

Each subject was given a test meal on three successive days after fasting for 12 hours. The composition of the test meals and the order of their ingestion were as follows:-

(1) $750 \mathrm{ml}$. of a solution containing $35 \mathrm{~g}$. sucrose/litre

(2) $750 \mathrm{ml}$. of distilled water

(3) $750 \mathrm{ml}$. of a solution containing $100 \mathrm{mEq}$. saline/ litre

These three meals were chosen because they produce three grades of emptying due to variations in their influence upon the duodenal receptors which act as brakes on gastric outflow.

* Present address: Department of Physiology, Guy's Hospital Medical School, London, S.E.1.
(1) The sucrose has a marked action upon duodenal receptors and slows the emptying of the stomach, i.e., prolongs the period of gastric distention.

(2) Distilled water exerts a moderate influence on duodenal osmo-receptors in that the emptying is faster than with the sucrose meal.

(3) The saline meal exerts a minimal influence on duodenal osmo-receptors, and the rate of gastric emptying is therefore the fastest of the three (Hunt, 1956).

Each meal also contained phenol red which was used as an indicator of the dilution of the gastric contents (Hunt and Spurrell, 1951). Before each meal a tube was passed and the stomach washed out with tap water. The meal was then given down the tube direct into the stomach. All the saliva was aspirated during the period of ingestion. The whole of the gastric contents was recovered after 30, 20, and 10 minutes' ingestion of the sucrose, water, and saline meals respectively.

The estimations and calculations used were those described by Hunt and Spurrell (1951) except that pepsin was estimated by the method of Anson and Mirsky (1932).

\section{RESULTS}

These are seen in Table I and are expressed as mean values together with the standard deviation for each group and each type of meal. Table II gives the $p$ values when the findings in the Bantu groups are compared with those in the European group.

RATE OF EMPTYING.-Since meals were of known volume $(750 \mathrm{ml}$.) the volume of a meal remaining at the end of the experimental period was taken as an index of the emptying rate during that period. The volume of a meal remaining was estimated by 
TABLE I

MEANS AND STANDARD DEVIATIONS OF DATA FROM THREE TYPES OF TEST MEAL IN THREE GROUPS OF SUBJECTS

\begin{tabular}{|c|c|c|c|c|c|c|c|c|c|}
\hline \multirow[b]{2}{*}{ Meal } & \multicolumn{3}{|c|}{ Sucrose } & \multicolumn{3}{|c|}{ Water } & \multicolumn{3}{|c|}{ Saline } \\
\hline & Europeans & \begin{tabular}{|c|} 
Bantu \\
Laboratory \\
Assistants
\end{tabular} & $\begin{array}{c}\text { Bantu } \\
\text { Under- } \\
\text { graduates }\end{array}$ & Europeans & \begin{tabular}{|l|} 
Bantu \\
Laboratory \\
Assistants
\end{tabular} & $\begin{array}{l}\text { Bantu } \\
\text { Under- } \\
\text { graduates }\end{array}$ & Europeans & $\begin{array}{c}\text { Bantu } \\
\text { Laboratory } \\
\text { Assistants }\end{array}$ & $\begin{array}{l}\text { Bantu } \\
\text { Under- } \\
\text { graduates }\end{array}$ \\
\hline $\begin{array}{l}\text { Mean volume of meal remaining } \\
\text { (ml.) } \\
\text { Mean concentration of } \mathrm{H}^{+}\end{array}$ & $\begin{array}{r}285 \\
\pm 103 \\
\end{array}$ & $\begin{array}{l}201 \\
121\end{array}$ & $\begin{array}{r}303 \\
68\end{array}$ & $\begin{array}{l}377 \\
101\end{array}$ & $\begin{array}{r}276 \\
95\end{array}$ & $\begin{array}{r}321 \\
63\end{array}$ & $\begin{array}{l}433 \\
101\end{array}$ & $\begin{array}{l}278 \\
134\end{array}$ & $\begin{array}{r}473 \\
68\end{array}$ \\
\hline $\begin{array}{l}\text { (mEq./1.) in gastric contents } \\
\text { Mean concentration of } \mathrm{Cl}^{-} \text {S.D. }\end{array}$ & $\begin{array}{r}13 \cdot 1 \\
\pm \quad 8 \cdot 2\end{array}$ & $\begin{array}{l}6.9 \\
4.7\end{array}$ & $\begin{array}{l}7.0 \\
5.3\end{array}$ & $\begin{array}{r}10.9 \\
7.1\end{array}$ & $\begin{array}{l}7.7 \\
4.7\end{array}$ & $\begin{array}{l}6.2 \\
3.8\end{array}$ & $\begin{array}{l}5.1 \\
3 \cdot 2\end{array}$ & $\begin{array}{l}3.4 \\
2.0\end{array}$ & $\begin{array}{l}2 \cdot 5 \\
2 \cdot 1\end{array}$ \\
\hline (mEq./1.) in gastric contents & $\begin{array}{r}24 \cdot 9 \\
\pm 13 \cdot 3\end{array}$ & $\begin{array}{r}18 \cdot 2 \\
7 \cdot 7\end{array}$ & $\begin{array}{r}15 \cdot 8 \\
3 \cdot 2\end{array}$ & $\begin{array}{r}16 \cdot 1 \\
8 \cdot 6\end{array}$ & $\begin{array}{r}14.6 \\
5.7\end{array}$ & $\begin{array}{r}12.6 \\
3.4\end{array}$ & 二 & 二 & 二 \\
\hline $\begin{array}{l}\text { (mg. tyrosine/1.) in gastric con- } \\
\text { tents } \\
\text { Mean amount of } \mathrm{H}^{+}(\mathrm{mEq} .) \\
\text { Mean amount of } \mathrm{Cl}^{-}(\mathrm{mEq} .) \\
\text { S.D. } \\
\begin{array}{c}\text { Mean amount of pepsin (mg. } \\
\text { tyrosine) }\end{array}\end{array}$ & $\begin{aligned} 17 \cdot 1 \\
\pm \quad 8 \cdot 8 \\
8 \cdot 0 \\
\pm \quad 5 \cdot 3 \\
15 \cdot 3 \\
+8 \cdot 1 \\
10 \cdot 5 \\
\pm \quad 5 \cdot 3\end{aligned}$ & $\begin{array}{c}10 \cdot 4 \\
7 \cdot 0 \\
4 \cdot 0 \\
2 \cdot 6 \\
10 \cdot 5 \\
4 \cdot 5 \\
6 \cdot 0^{*} \\
3 \cdot 6\end{array}$ & $\begin{array}{l}6.8 \\
5.3 \\
4 \cdot 3 \\
3 \cdot 2 \\
9 \cdot 5 \\
2 \cdot 1 \\
4 \cdot 1 \\
4 \cdot 3\end{array}$ & $\begin{array}{r}13 \cdot 3 \\
7 \cdot 1 \\
6 \cdot 3 \\
4 \cdot 2 \\
10 \cdot 1 \\
5 \cdot 2 \\
8 \cdot 1 \\
4 \cdot 0\end{array}$ & $\begin{array}{l}7 \cdot 6 \\
4 \cdot 2 \\
4 \cdot 4 \\
2 \cdot 7 \\
8 \cdot 6 \\
3 \cdot 7 \\
4 \cdot 5 \\
2 \cdot 5\end{array}$ & $\begin{array}{l}8 \cdot 8 \\
4 \cdot 1 \\
3 \cdot 7 \\
2 \cdot 2 \\
7 \cdot 3 \\
1 \cdot 9 \\
5 \cdot 1 \\
2 \cdot 4\end{array}$ & $\begin{array}{r}10 \cdot 6 \\
6.1 \\
3 \cdot 7 \\
2 \cdot 3 \\
\frac{7}{6 \cdot 9} \\
4 \cdot 1\end{array}$ & $\begin{array}{l}8 \cdot 8 \\
5.5 \\
2 \cdot 0 \\
1 \cdot 1 \\
\bar{~} \overline{5 \cdot 2} \\
3 \cdot 4\end{array}$ & $\begin{array}{l}4.2 \\
4.3 \\
1.8 \\
1.5 \\
= \\
\frac{2.8}{3.1}\end{array}$ \\
\hline
\end{tabular}

*Values where the significance of the difference from the European group is greater than 1 in 20 are in bold type.

TABLE II

VALUES OBTAINED BY COMPARISON OF MEANS FROM EUROPEAN GROUP WITH TWO BANTU GROUPS

\begin{tabular}{|c|c|c|c|c|c|c|c|}
\hline $\begin{array}{l}\text { Responses to Test Meals in } \\
\text { European Group Compared with }\end{array}$ & $\begin{array}{l}\text { Vol. of Meal } \\
\text { Remaining }\end{array}$ & {$\left[\mathbf{H}^{+}\right]$} & Amount $\mathbf{H}^{+}$ & {$\left[\mathrm{Cl}^{-}\right]$} & Amount $\mathrm{Cl}^{-}$ & [Pepsin] & $\begin{array}{l}\text { Amount } \\
\text { Pepsin }\end{array}$ \\
\hline $\begin{array}{l}\text { Sucrose Meal } \\
\text { (a) Bantu laboratory assistants } \\
\text { (b) Bantu undergraduates } \\
\text { (c) Groups (a) and (b) combined }\end{array}$ & $\begin{array}{l}0 \cdot 1 \\
0 \cdot 5 \\
0 \cdot 4\end{array}$ & $\begin{array}{l}0.1-0.05 \\
0.1 \\
0.025\end{array}$ & $\begin{array}{l}0.1-0.05 \\
0.1-0.05 \\
0.025-0.01\end{array}$ & $\begin{array}{l}0.3 \\
0.1-0.05 \\
0.05\end{array}$ & $\begin{array}{l}0.2-0.1 \\
0 \cdot 1=0.05 \\
0.025\end{array}$ & $\begin{array}{l}0 \cdot 1 \\
0.01 \\
0 \cdot 005\end{array}$ & $\begin{array}{l}0.05 \\
0.01 \\
0.005-0.001\end{array}$ \\
\hline $\begin{array}{l}\text { Water Meal } \\
\text { (a) Bantu laboratory assistants } \\
\text { (b) Bantu undergraduates } \\
\text { (c) Groups (a) and (b) combined }\end{array}$ & $\begin{array}{l}0.05 \\
0.2 \\
0.05\end{array}$ & $\begin{array}{l}0 \cdot 3 \\
0 \cdot 1 \\
0 \cdot 1\end{array}$ & $\begin{array}{l}0.4-0.2 \\
0.2-0.1 \\
0.1\end{array}$ & $\begin{array}{l}0.6 \\
0.3 \\
0.3\end{array}$ & $\begin{array}{l}0.5-0.4 \\
0.2-0.1 \\
0.2\end{array}$ & $\begin{array}{l}0.05 \\
0.2-0 \cdot 1 \\
0.025\end{array}$ & $\begin{array}{l}0.05-0.025 \\
0.1-0.05 \\
0.01\end{array}$ \\
\hline $\begin{array}{l}\text { Saline Meal } \\
\text { (a) Bantu laboratory assistants } \\
\text { (b) Bantu undergraduates } \\
\text { (c) Groups (a) and (b) combined }\end{array}$ & $\begin{array}{l}0.005 \\
0.3 \\
0.2\end{array}$ & $\begin{array}{l}0.2 \\
0.1-0.05 \\
0.05-0.025\end{array}$ & $\begin{array}{l}0.1-0.05 \\
0.1-0.05 \\
0.025-0.01\end{array}$ & $\overline{-}$ & $\overline{-}$ & $\begin{array}{l}0.5 \\
0.025 \\
0.1-0.05\end{array}$ & $\begin{array}{l}0.4-0.2 \\
0.025 \\
0.05\end{array}$ \\
\hline
\end{tabular}

A significance greater than 1 in 20 is shown in bold type.

multiplying the volume of the gastric recovery by the percentage of the marker dye, phenol red, in the recovery.

There was no difference between the groups in the volume of test meal remaining after the sucrose meal. With the water and saline meals the Bantu laboratory assistants had a significantly smaller volume of the meal remaining than the Europeans, but this was not so with the Bantu undergraduates (Fig. 1). One striking feature of the gastric findings was that in response to the sucrose and saline meals the Bantu undergraduates had a significantly larger volume of meal remaining than the Bantu laboratory assistants, this being the only difference in gastric behaviour found between the two Bantu groups.

CONCENTRATION of $\mathrm{H}^{+}$.- There was a tendency for the Bantu to have a lower $\mathrm{H}^{+}$concentration in the gastric contents than the Europeans. If, however, the $\mathrm{H}^{+}$concentrations of the two Bantu groups are combined and the mean value of the combination compared with the mean European $\mathrm{H}^{+}$concentra- tion, then a lower $\mathrm{H}^{+}$value is shown by the Bantu for the sucrose and saline meals, the difference being statistically significant.

AMount of $\mathrm{H}^{+}$.- The amount of $\mathrm{H}^{+}$secreted in response to a test meal has been calculated from the amount in the gastric contents with the addition of an amount derived from the calculation of the volume of gastric contents passing the pylorus. The amount of $\mathrm{H}^{+}$thus calculated is lower in response to the sucrose and saline meals in each Bantu group than in the European group $(P=0.1-0.05)$ but responses to water meals show no difference (Fig. 2).

CONCENTRATION OF ChLORIDE.-No estimation of chloride $\left(\mathrm{Cl}^{-}\right)$was made in the response to the saline meal. With the other two meals the comparison between the European and Bantu groups show that, like the $\mathrm{H}^{+}$concentration, the $\mathrm{Cl}^{-}$concentration tends to be less in the Bantu in response to the sucrose meal, a difference which is statistically significant if values from both Bantu groups are 


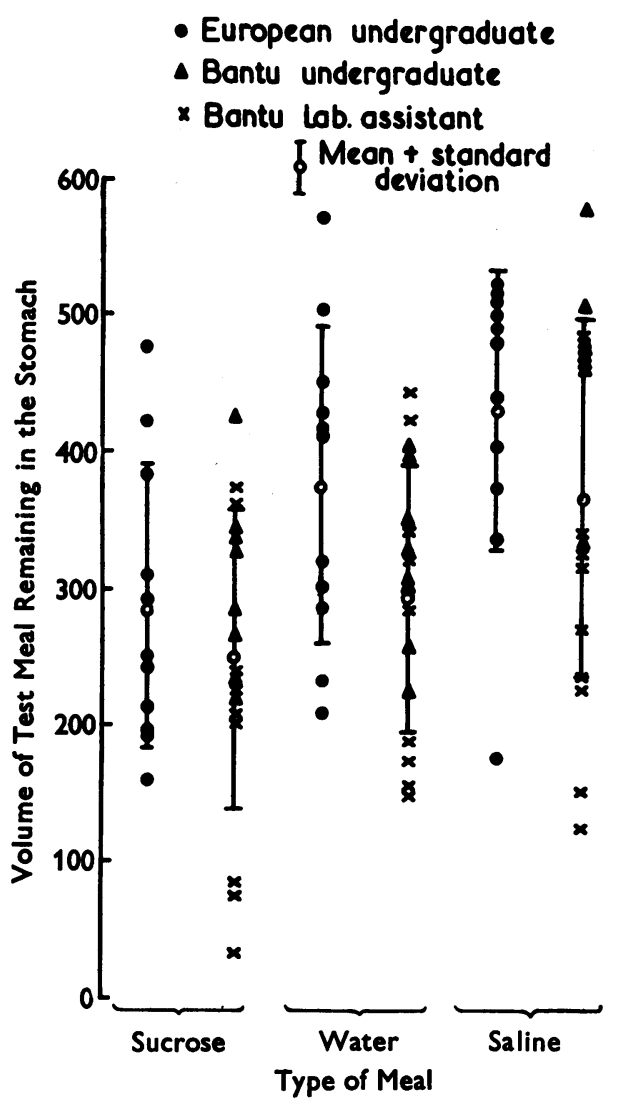

FIg. 1.-Volume of test meal remaining in the stomach plotted against the type of meal for each racial group.

combined, whereas no difference is seen in the $\mathrm{Cl}^{-}$ concentration of the racial groups in response to the water meal.

Amount of ChLORIDE.-The amount of $\mathrm{Cl}^{-}$tends to be less in both Bantu groups than in the European group, in response to the sucrose meal, a difference which becomes statistically significant when the two Bantu groups are combined. No difference in the amount of $\mathrm{Cl}^{-}$secreted is seen in the responses to the water meal (Fig. 3).

Concentration of Pepsin.-The concentration of pepsin tends to be less in the gastric response of both Bantu groups than in the European, and when the combined Bantu group is compared with the European group the difference becomes statistically significant in response to the sucrose and water meals and in the saline meal the value of $P$ is $0 \cdot 1-0.05$.

AMOUNT OF PEPSIN.-The amount of pepsin was significantly less in each Bantu group in every meal except the Bantu undergraduates' response to the water meal and the Bantu laboratory assistants' response to the saline meal. All the combined Bantu group mean pepsin amount was less than that in the European group (Fig. 4).

\section{Discussion}

The results show that the Bantu secrete less acid and pepsin than the Europeans under similar circumstances, and also that the Bantu have lower concentrations of acid and pepsin in the gastric contents. If the concentration of $\mathrm{H}^{+}$and pepsin must reach a certain level before duodenal ulceration can occur then the Bantu are further away from this level than the Europeans and would require a greater secretory effort to reach the threshold of duodenal trauma. This may be one reason why duodenal ulceration is apparently less frequent in the South African Bantu compared with the Europeans in the same region.

Direct comparative studies with Europeans have not been done but Barnes and Gordon (1937) found a tendency to a lower acidity of gastric contents in

- European undergraduate

- Bantu undergraduate

$x$ Bantu lab.assistant

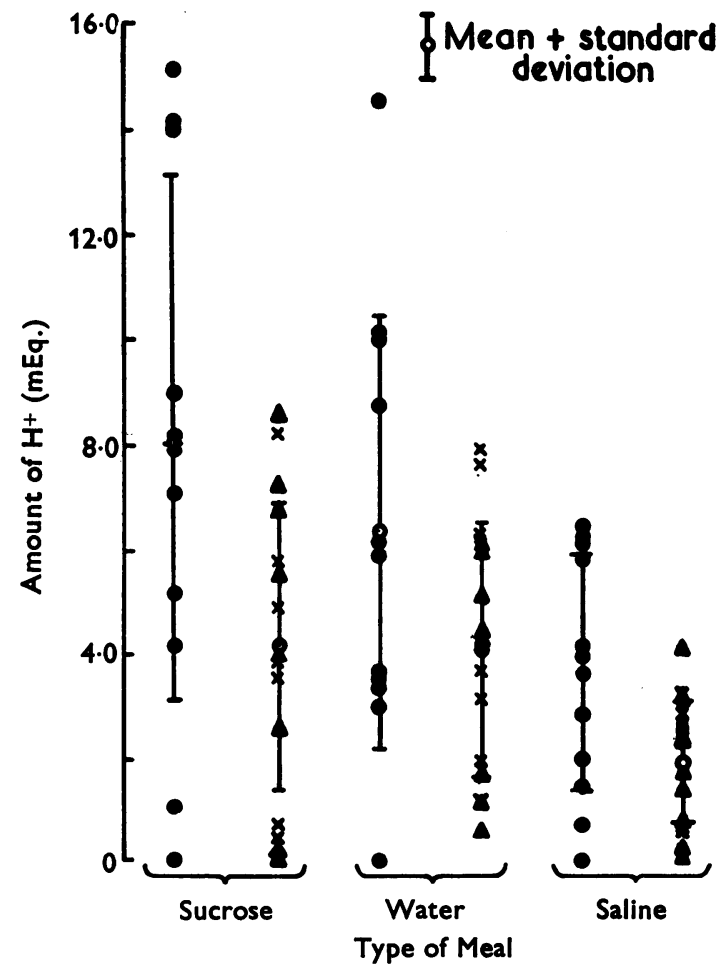

Fig. 2.-Amount of $\mathrm{H}^{+}$plotted against the type of meal for each racial group. 
- European undergraduate

- Bantu undergraduate

$x$ Bantu lab. assistant

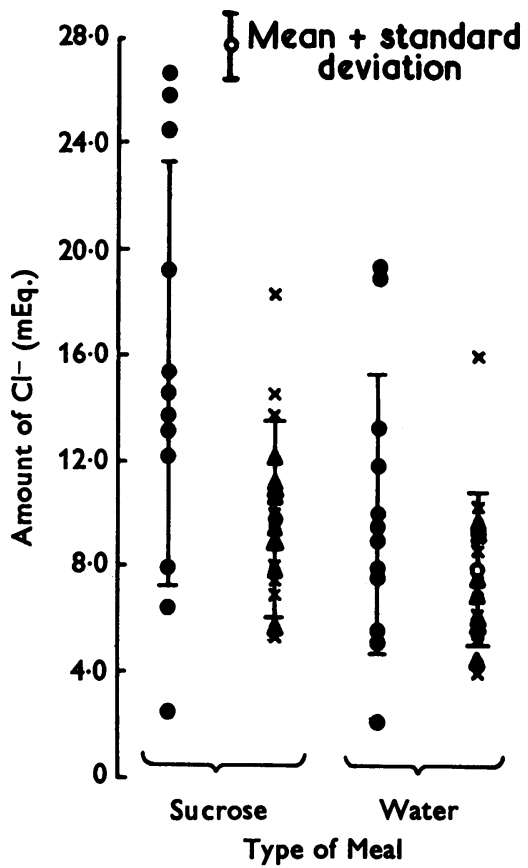

Fig. 3.-Amount of $\mathrm{Cl}^{-}$-plotted against the type of meal for each racial group.

the South African Bantu than that usually found in similar tests on Europeans, whereas normal Bantu in southern Nigeria (Ellis, 1934) had a mean "free acid" very similar to that described in European medical students by Bennett and Ryle (1921).

The individual measurements obtained here cannot be compared with those obtained by fractional test meals, though the results from southern Nigeria suggest no racial difference as compared with the European. However, the response (except pepsin) to the water and saline meals can be compared with the findings in male medical students in London described by Booth, Hunt, Miles, and Murray (1957). The mean values of these workers' findings are all lower than those in the European undergraduates in Johannesburg, but higher than in the Bantu group. The significance of this finding is not clear.

If it is not genetics that accounts for the lower acid and pepsin production of the stomach of the South African Bantu, then can it be that diet is responsible?

It was for this reason that the gastric behaviour of the Bantu undergraduates was studied. The difference in gastric activity that was apparent between the Europeans and the Bantu laboratory assistants might have been due to diet, therefore the Bantu undergraduates were examined as they all lived in residence on a European diet. In actual fact no difference was found in the gastric secretory response between the two Bantu groups. As the undergraduates had been in residence for periods from six months to three years with breaks for vacation, and as the previous vacation away from the residence was approximately six months before the test meals in most of the Bantu undergraduates, whereas the laboratory assistants lived in their own quarters, it can be concluded that current dietary habits played no significant part in determining the gastric secretory response to test meals.

With regard to the rate of gastric emptying as assessed by the volume of test meal remaining, there are in the sucrose and saline meals significant

- European undergraduate

$\triangle$ Bantu undergraduate

$\times$ Bantu lab. assistant

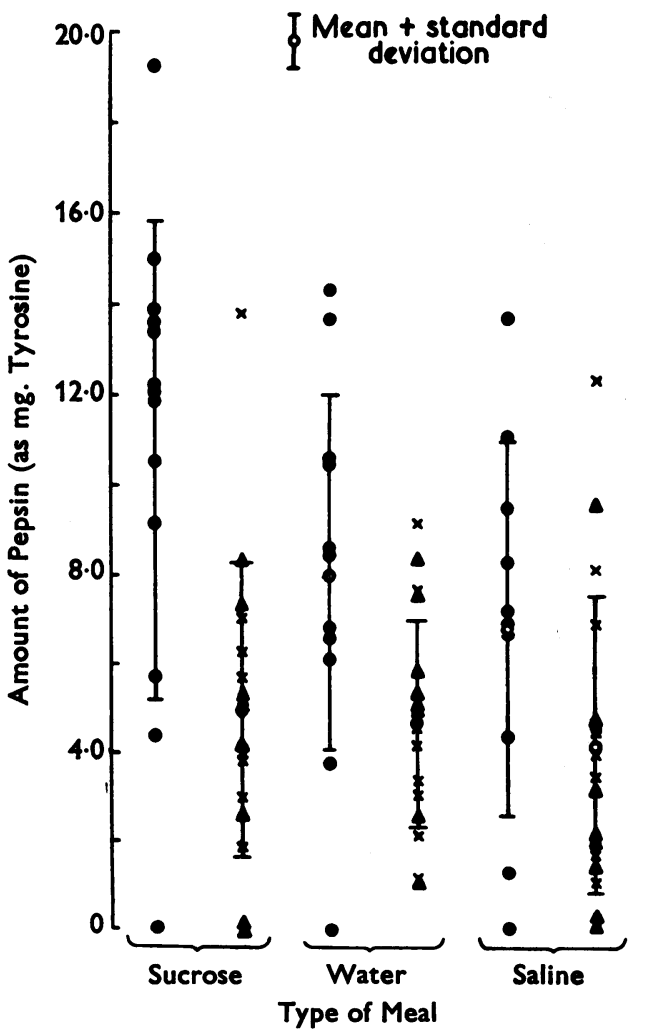

FIG. 4.-The amount of pepsin plotted against the type of meal for each racial group. 
differences in response between the two Bantu groups, the undergraduate group having values approximating those found in the European undergraduates. This difference may well be dietetic, not so much in the composition of the diet perhaps but in the volume normally consumed. The meals of the laboratory assistants tend to be more bulky than western diets and this may be responsible for the more rapid gastric emptying seen in the laboratory assistant group.

Konstam (1954) believes that diet plays an important role in the pathogenesis of duodenal ulcer, and it has been shown by using fractional test meals (Ellis, 1934; Konstam, 1955) that ulcer patients in southern Nigeria have a higher free acid than controls. Therefore, by implication, the diet would appear to be associated with the degree of acidity of gastric contents. Rose (1935), also using fractional test meals, found that many natives of northern Nigeria exhibit a degree of acidity which is high compared with European standards, and he suggested that this difference in level of acidity is dietary in origin. In the present series it does not appear that a direct and immediate effect of diet influences gastric secretory activity, as the Bantu undergraduates who have been on a European diet do not show gastric secretory activity similar to that in the Europeans but rather like that in the Bantu laboratory assistants whose diet consists largely of maize.

I am most grateful to the volunteers who made this work possible. I also wish to thank Mr. A. Martin for assistance with the pepsin estimations and the Peel Trust Fund of the Medical Research Council of Great Britain for a grant towards costs of travel.

\section{REFERENCES}

Anson, M. L., and Mirsky, A. E. (1932). J. gen. Physiol., 16, 59. Barnes, H. D., and Gordon, M. S. (1937). S. Afr. J. med. Sci., 2,75 .

Bennett, T. I., and Ryle, J. A. (1921). Guy's Hosp. Rep., 71, 286.

Booth, M., Hunt, J. N., Miles, J. M., and Murray, F. A. (1957). Lancet, 1, 657 .

Eagle, P. C., and Gillman, J. (1938). S. Afr. J. med. Sci., 3, 1.

Ellis, M. (1934). West Afr. med. J., 8, No. 2, p. 16.

Hunt, J. N. (1956). J. Physiol. (Lond.), 132, 267.

Hunt, J. N. (1956), J. Physiol. (Lond.), 132, 267 ,

Konstam, P. G. (1954). Lancet, 2, 1039.

Rose, (1955); West Afr. med. J., n.s. 4, 203. 